Article

\title{
From Counter-Power to Counter-Pepe: The Vagaries of Participatory Epistemology in a Digital Age
}

\author{
C. W. Anderson * and Matthias Revers \\ School of Media and Communication, University of Leeds, Leeds, LS2 9JT, UK; E-Mails: c.w.anderson@leeds.ac.uk (C.W.A.), \\ m.revers@leeds.ac.uk (M.R.) \\ * Corresponding author
}

Submitted: 23 March 2018 | Accepted: 22 June 2018 | Published: 8 November 2018

\begin{abstract}
This article reconstructs the evolution of societal and journalistic meta-discourse about the participation of ordinary citizens in the news production process. We do so through a genealogy of what we call "participatory epistemology", defined here as a form of journalistic knowledge in which professional expertise is modified through public interaction. It is our argument that the notion of "citizen participation in news process" has not simply functioned as a normative concept but has rather carried with it a particular understanding of what journalists could reasonably know, and how their knowledge could be enhanced by engaging with the public in order to produce journalistic work. By examining four key moments in the evolution of participatory epistemology, as well as the discursive webs that have surrounded these moments, we aim to demonstrate some of the factors which led a cherished and utopian concept to become a dark and dystopian one. In this, we supplement the work of Quandt (2018) and add some historical flesh to the conceptual arguments of his article on "dark participation".
\end{abstract}

\section{Keywords}

Andy Carvin; Buzzfeed; citizen journalism; Indymedia; meta-discourse; memes; participatory epistemology; Pepe the Frog; populism; trolls

\section{Issue}

This article is part of the issue "News and Participation through and beyond Proprietary Platforms in an Age of Social Media", edited by Oscar Westlund (Oslo Metropolitan University, Norway) and Mats Ekström (University of Gothenburg, Sweden).

(C) 2018 by the authors; licensee Cogitatio (Lisbon, Portugal). This article is licensed under a Creative Commons Attribution 4.0 International License (CC BY).

\section{Introduction}

As Kreiss and Brennen (2016) have perceptively noted, "participation" is one of the guiding normative values of journalism in the digital age. "To overcome the industrial production of journalism and culture", they have argued "[journalism] reformers elevated participation as a primary democratic value" (Kreiss \& Brennen, 2016, p. 301). This conclusion about the importance, and ultimate fragility, of the participatory concept is echoed by Quandt (2018). In this article, we attempt to expand on the manner by which this central value has evolved and transformed over the course of the internet's threedecade existence by reconstructing the evolution of soci- etal and journalistic meta-discourse about the participation of ordinary citizens in the news production process.

It is one of the central arguments that this desire for a more authentic participatory community is inherently political and is much older than the internet itself. It can at least be traced back to the New Left's call for greater public involvement in politics and the more circumscribed call for a political, participatory journalism. One of the New Left's more general aims for participatory democracy was "that society be organized to encourage independence in men and provide the media for their common participation" (Students for a Democratic Society, 1962). The Port Huron Statement further laid out the institutional arrangement required for realizing this 
vision, which we would nowadays associate with participatory media spaces, amongst other places:

Mechanisms of voluntary association must be created through which political information can be imparted and political participation encouraged....Institutions should be created that engage people with issues and express political preference,... which carry political influence (appropriate to private, rather than public, groupings) in national decision-making enterprise. Private in nature, these should be organized around single issues (medical care, transportation systems reform, etc.), concrete interest (labor and minority group organizations), multiple issues or general issues....They would be a significant politicizing and educative force bringing people into touch with public life and affording them means of expression and action. (Students for a Democratic Society, 1962)

In an attempt to probe the discursive and political nexus in which these various notions of participatory journalism emerged and evolved, we follow in the footsteps of Fred Turner's research on the relationship between the "hippie" values of 1960s and 70s California and the early notion of a radically free, communalist internet (Turner, 2006). We think there is a parallel, more East Coast-oriented story to be told about how journalistic participation evolved and the way that the "do-ityourself" (DIY), radically anarchistic media production of the 1990s, spawned, uneasily, today's weaponized meme-warfare and culture of "fake news". In telling this story we do not mean to condemn all varieties of participatory journalism or to claim that they are all the same. We do mean to complicate the history of journalistic participation and thus further problematize this "participation" as a journalistic value and an underlying journalistic epistemology. It is also important to note that it is not our argument that there has been an inevitable "descent" of participatory epistemology from utopian heights to a sordid and "dark" reality (Quandt, 2018). Rather, the conversation surrounding journalistic participation has, indeed, grown darker. But why, and to what end?

In this spirit, and in the pages below, we chronicle four key discursive inflection points through four brief genealogical case studies. We begin by briefly defining what we mean by "participatory epistemology" and outlining how the normative value of "participation" was fused with an epistemological and professional understanding of what participation meant for what journalists could possibly "know". We then turn to our first case study, the Independent Media Center movement, a collective of linked websites launched in 1999 in the aftermath of the World Trade Organization (WTO) protests in Seattle to provide coverage of anti-globalization protests from an activist point of view. As one of the first websites to allow news events to be uploaded to the world wide web as they occurred (Anderson, 2013; Wolfson, 2015), Indymedia would spawn a variety of affiliated "citizen media" projects. This article discusses how Indymedia's primary accomplishment was to enable the fusion of DIY cultures of craft production and identity-based community media initiatives, both of which reached their peak in the pre-internet days of the early 1990s.

Early DIY digital journalism work was largely the domain of the political left and was specifically framed in opposition to professional journalism. Our website "will focus on the protests, actions and issues ignored by conventional media sources", Indymedia organizers wrote. Soon, however, professional journalism itself would attempt to adopt a participatory mindset. In light of the dire economic situation of legacy news organizations and the loss of discursive influence with the rise of usergenerated and other news-like content, journalists in the US were compelled to open up to more participatory forms of communication around 2010, especially on Twitter. Besides the possibility of live coverage, tweeting meant that journalists, at the very least, could become more personally involved and accessible to other users in the process of creating news. But this did not exhaust social media's participatory affordances, especially the role assigned to citizens, not only as interlocutors but also sources and co-creators of news. We discuss Andy Carvin as a role model of this more expansive conception of participatory journalism. In contrast to this, media scholars were mostly dissatisfied with the adoption of social media in practice, which reflected fundamental tensions between participatory and professional cultures.

The importance of Twitter in the above narrative highlights a third evolutionary change in our storythe emergence of internet "platforms" as the dominant mechanism of digital communication and the accompanying massification-individualization of participatory media making. With the growth of Facebook and Youtube (and to a lesser extent, Twitter, Snapchat, and Instagram) creating and sharing journalistic content moved from a fringe activity to a mass activity, with industrial level developments affecting formerly "alternative" media patterns. While there is an entire academic genre of "platform studies" (Bogost \& Montfort, 2009; Gillespie, 2010; Helmond, 2013), this piece analyzes this shift obliquely, by briefly considering the career and ideological work of Jonah Peretti, the founder of Buzzfeed and a key link between older genres of media production and newer, more capital-intensive notions of participatory production and sharing.

Our final case study takes us up to the present day, looking at how the conversation around participatory platforms have again evolved in the aftermath of Brexit, Donald Trump, and the rise of 4 Chan and Reddit. While platform power sat uneasily within older strands of production that also valorized the actions of ideologically committed citizens, the combined impact of populism, propaganda, and misogyny have soured even the most optimistic takes. Academic arguments about media and participation have also broken out of their media studies cul-de-sac and are also now the domain of "more se- 
rious" branches of scholarship such as political communication and more critically minded researchers of race, gender and social class. We conclude by reviewing these developments and discussing some paths forward for future scholarship.

\section{What Is "Participatory Epistemology"?}

The following pages largely discuss participation as a normative ideal; that is, as a way of thinking about an emerging relationship between citizens and journalists that, over time, accreted a certain set of values. But audience participation in the journalistic process also carried with a particular understanding of what journalists could reasonably know, and how their knowledge could be enhanced by engaging with the public in order to produce journalistic work. Participatory epistemology, defined here as a form of journalistic knowledge in which professional expertise was modified through public interaction, was largely based on two separate but related notions of how citizen engagement in the news process could improve journalism. The first is largely "cybernetic" in orientation and sees the relationship between news producers, products, and consumers as part of a series of feedback loops in which digital communication acts as a functional bridge that improves the accuracy and relevance of news products. The second is largely deliberative, in which digital journalists are understood as embedded in a "conversation" with citizens, one that produces a journalism more likely to incorporate the perspectives and points of view of ordinary people. Both these epistemologies functionally denigrate traditional journalistic knowledge, seeing it as inadequate or incapable of maintaining its relevance in the 21st century digital media environment.

We now analyze how this participatory epistemology, defined above, emerged and developed over time by briefly looking at four case studies.

\section{Indymedia and the DIY Moment}

Once a major object of study amongst critically-inclined journalism scholars and internet theorists, academic research on the Indymedia phenomenon has waned in tandem with the decline and disappearance of the movement itself. ${ }^{1}$ In one of the earliest articles on Indymedia, Platon and Deuze (2003, p. 337) described what they called "a radical way of making, selecting and sharing news...published on a website, which has possibilities for archiving and structuring incoming news in a way that traditional media (print, television and video) cannot". They and other early scholars chronicle an "open-source news process" in which left-wing, largely anarchist media activists used both structured community participation (in the form of an "open newswire" to which anyone could upload breaking news or political commen- tary) and editorial oversight (with centrally and collectively chosen "feature stories") to create a participatory news website particularly active during moments of political protest and unrest. At its peak Indymedia websites existed in over 230 locations on six continents, with a small group of regular editors providing curated content touching on a variety of left-wing activist concerns and a larger group of contributors congregating on the site during local protest actions and moments of high political drama (in New York City after September 11, 2001, for instance). The flat structure of IMC network allowed content to be shared across different sites and also encouraged a central website (indymedia.org) to act as a content curator that could highlight different local stories. Since at least 2006, however, the network has experienced almost a complete collapse, with sites shuttering and many others existing in a sort of "ghost" status. Ironically, the decentralized and anarchistic nature of Indymedia governance makes actually closing these potemkin sites difficult, making it difficult to determine the exact health of the network. And although she argues that the Indymedia experiment has not necessarily failed, the most recent and optimistic scholarship on the topic by Eva Giraud (2014, p. 420) admits that "[the] network as a whole has declined".

Despite being nourished by numerous intellectual and technological predecessors (the list runs from the participatory media philosophies of the Zapatista movement in the 1990s to the BURN! Collective at the University of California San Diego; Wolfson, 2015) with the benefit of hindsight it seems clear that Indymedia was the first journalistic project to both emphasize the benefits of "participatory journalism" and capture wider public attention, particularly from other journalists. In part, this attention was facilitated by a growing interest in the participatory potentials and affordances of digital technology, which allowed networked and decentralized participation in the journalistic process from a variety of ideological actors. Wolfson, in fact, contends it was this focus on aggressively horizontal governance processes and a fetishization of digital technology that lead to the ultimate failure of the Indymedia project, particular insofar as the core of the IMC neglected to engage in any meaningful fashion with local activists and their longterm community-based concerns. Indymedia, in short, focused on politics and technology and neglected the real work of building a grounded movement culture that could be sustained over the long term (Wolfson, 2012).

We want to take slight issue with this conclusion in a way that points both backwards and forwards towards our main argument. With the benefit of hindsight and history, it seems clear that the primary accomplishment of Indymedia (along with related media forms like blogging, podcasting, and webzine production) was to bring "do-ityourself (DIY) maker politics" out of the realm of strictly cultural practice and into the realm of both professional

\footnotetext{
${ }^{1}$ In 2003 Google Scholar records 462 mentions of 'Indymedia'. The scholarly citation rate reached 1020 mentions in 2010 , with a steady decline to 531 mentions in 2017.
} 
journalism and "hard" politics. In other words, there was a culture of Indymedia-a thin but globalized culture of DIY practitioners who valorized small-scale craft production in opposition to culture produced by corporations. These "alternative media makers" included the producers of 'zines, low-power radio, punk music, and community newspapers. As Ratto and Boler (2014, p. 10; see also Day, 2016) write:

By the late 1980s and early 1990s, DIY culture had evolved with the innovative emergence of zines, a significant cultural production practice of both punk and third-wave feminist cultures....People around the globe were enacting forms of protest and direct action that increasingly wedded art and politics.....Indeed, this conjunction between art and protest has only snowballed over the ensuing decades; feminist artists working in craft and activism, which continues the legacy of DIY culture.

Indymedia, then was able to act as a discursive and rhetorical bridge between these fairly marginal maker communities and the larger, more powerful spheres of digital technology and professional journalism. As Giraud (2014, p. 425) notes:

Radical activist media projects such as Indymedia gave momentum to a celebratory narrative that foregrounded the participatory potential of digital media [see, e.g., Allan, 2006; Castells, 1997; Gilmor, 2006], but the network's position in that narrative has since been displaced with discourses of "Twitter revolutions".

We would contend that it was not an accident that Indymedia was able to play this bridging role. It was, in fact, deeply grounded in the culture of the platform itself. IMCs tapped into both an older (DIY) and emerging (techno-participatory) rhetoric that emphasized participation as a leading value in and of itself in domains of cultural production (the provision of small-scale consumerist alternatives) personal self-actualization (the pedagogic values of participatory culture, particularly in politics) and structural journalism reform (the ability to reduce the power of the corporate, ideologically blinkered media). And although these values aligned themselves to a resolutely left-of-center, anarchist politics, such an affiliation was not a given-as the following sections will show.

In his influential overview of how the origins of Silicon Valley could be found, in part, in the libertarian values of the 1960s and 70s counter-culture, Fred Turner draws our attention to the manner by which alternative modes of living and creating often serve as the incubators and harbingers of decidedly more capitalistic enterprises. While our argument here is more restricted than Turner's deeply researched account, we would argue that the origins of the participatory journalism epistemology might be found in a similar fusion of "do it yourself" values and anti-institutional politics, which itself might be traceable back to its New Left origins and perhaps even further. The next sections will elaborate the further (and surprising) evolutions of this journalistic epistemology. As blogs, podcasts, and other more digital formats of news replaced organizations like Indymedia, and as the rhetoric of do-it-yourself journalism increased in both volume and stridency, professional news organizations themselves were compelled to reckon with this participatory journalistic turn.

\section{Professional Adaptation to Participatory Practices}

By the early 2000s, journalism was pushed from two directions to adopt participatory practices. From above, by the underfunded organizations employing them and which were desperate for new sources of revenue and relevance on the web. From below, by the growing prevalence and increasing professionalization of blogs and other online news ventures which grew out of open source news production. Liberal political blogs in the US, like Daily Kos or Talking Points Memo, and conservative blogs, like Drudge Report and Michelle Malkin, provided quick and opinionated takes on the news to growing audiences.

After establishing online news platforms in the mid to late 1990s, which initially followed traditional production principles (Boczkowski, 2004), many legacy news organizations started blogs in the mid-2000s. Aside from journalism itself, blogging was seen as a potential paradigm shift for audience engagement in professional discourse:

When journalism becomes a process...audiences discard their traditional role as passive consumers of news and become empowered partners with a shared stake in the end result. Weblogs offer one way to promote that kind of interactivity. (Lasica, 2003)

However, academic dissatisfaction with the practical implementation of "j-blogs" was not uncommon. They were often criticized as mere strategies to reassert gatekeeping power rather than genuine attempts to enter in a more engaged dialogue with the public (see Singer, 2005).

When they established blogs, newspaper editors had most likely their publications' survival on their minds rather than the enhancement of public dialogue. For newspapers, the possibility of more immediately breaking and shaping the news through blogging represented a promising response to the general diversion of attention on the web. They frequently accomplished this by hiring bloggers, as did the Washington Post with Ezra Klein in 2009 or the New York Times with Brian Stelter in 2007. Bloggers brought with them not only necessary practical skills, including the ability to quickly process and produce great amounts of information, but also a work ethic in which such "always on" production prac- 
tices were common. They also brought with them audiences of their own.

But the real hope for a more open and public journalism happened with the rise of social networking services-particularly Twitter. With its ability to organize and generate discourse in small dosages and engage with other users directly and publicly, was seen as the breeding ground for a new type of ambient journalism, which Hermida (2010, p 298) conceived as an awareness system that "provid[es] journalists with more complex ways of understanding and reporting on the subtleties of public communication".

The scholarly literature at that time is defined by optimism (or at least recognition of the potential) regarding the affordances of social media for more democratically valuable forms of journalism, marking a shift from the earlier academic skepticism. To just give two examples: news production, Sue Robinson (2010, p. 141) predicted, "is moving from a hierarchal [sic], centralized, one-to-many, unidirectional information flow to something more distributed, decentralized, poly-directional, many-to-many, pattern". Hermida (2012, p. 662) was hopeful that "journalists adopt a more collaborative method to determining the truth that, in theory, could be reached through an iterative process played out on networks such as Twitter". To be sure, neither author was blindly optimistic, but many scholars were certainly more optimistic than seems warranted today (see, also, Quandt, 2018).

Twitter's user base grew from 30 to 117 million between 2010 and 2011 (Team, 2016). It was not only the numbers, however, which brought Twitter on the map but its role in key historical events in this period. The excitement generated by the interactive and "witnessing" potentialities of Twitter (Zelizer, 2007; Peters, 2009) helped generate a professional and technological discourse around a new, archetypical professional journalist with both traditional news and social media credibility. Enter Andy Carvin, whose Twitter feed surged to prominence during the Arab Spring in 2011 and who had been a social media strategist at NPR since 2006. Carvin had made a name of himself as an internet activist and had been involved in early efforts to bridge digital divides and integrate the internet into school education in the late 1990s, as well as several citizen journalism initiatives, particularly after 9/11 and Hurricane Katrina.

The role Carvin assumed during the uprisings in the Middle East was that of a curator, which consisted of sourcing and assessing information by means of a large network of citizens and other journalists (Hermida, Lewis, \& Zamith, 2014). Though he curated remotely from the US, it was often emphasized that he had on-the-ground travel experience in Tunisia and Egypt. For media scholars who have long criticized journalism's over-reliance on official sources (Gans, 1979/2004; Sigal, 1973; Tuchman, 1978), Carvin's preference of "alternative voices" met normative expectations. He epitomized a kind of journalism which engages in "collaborative verification, trans- parency and co-creation" while conforming to established professional norms but performing more humbly and "open about the limits of his reporting" (García de Torres \& Hermida, 2017, pp. 177, 190, italics in the original).

Trade publications, such as Nieman Journalism Lab, agreed and saw his work as having "turned curation into an art form, and it's provided a hint of what news can look like in an increasingly networked media environment" (Garber, 2011). A portrait in Columbia Journalism Review, titled Is This the World's Best Twitter Account? (Silverman, 2011), listed several tweets which exemplified how Carvin engages his social network on Twitter, using it as direct sources or to confirm or explain information he received, while carefully noting the status of its confirmation. Most importantly, in the process of verification his role was to ascribe journalistic credibility to public information.

All was not simply pure utopianism, however, particularly in the realm of digital scholarship about social media. Under the surface of the happy and democratic ambient journalism, a broader disillusionment around the absent or insufficient enhancement and equalization of democratic discourse through the internet (Hindman, 2009), was also emerging. Some scholars criticized journalism blogs as means to extend proven ways of doing journalism and to maintain gatekeeping power (Robinson, 2006; Singer, 2005). Journalism researchers found similar tendencies with Twitter (Molyneux \& Mourão, 2017; Parmelee, 2013), though some to a lesser extent (Lasorsa, Lewis, \& Holton, 2012), which suggests that the normalization diagnosis can be attributed more to institutional inertia than steadfast institutional resistance to participatory practices.

To sum up, popular and scholarly narratives about the value of participation in this period were still influenced by the early utopian visions of the internet; specifically, the notion that the liberatory power of the internet would sweep away hardened anti-democratic inertia of professional journalism. However, the vision that through social media a more public journalism would emerge was quickly paired with dissatisfaction about the practical implementation of this vision. This dissatisfaction keyed into an established theme of media criticism, which has been taking issue with journalism's incessant reliance on elite sources and its insufficient openness to citizen for at least three decades. This found further support by evidence that suggest persistent dominance of official sources in times of more technology-enabled eventdriven news (Livingston \& Bennett, 2003).

In addition, and finally, Twitter was not simply a website on the internet; it was a social media platform, and Andy Carvin made his participatory name according to the rules and affordances of that platform. The importance of the platform nature of Twitter-and of platforms in general, and how they played into larger changes in the notion of participation and journalismwill become clearer in the next section. It is with this transition that the changes in the journalistic episte- 
mology of participation become both institutionalized and problematic.

\section{Buzzfeed, Virality, and the Path to Platforms}

In 2013, the internet got a good laugh when it discovered that Jonah Peretti, founder of the website Buzzfeed, had once attended the University of Santa Cruz, had hung around its' famous History of Consciousness program, and wrote an academic article on Deleuze, Guattari, and the production of consumer identity in late capitalism. Insofar as Buzzfeed (then best known for its viral headlines and content like "42 Pieces of Definitive Proof That You Might Possibly Be Armenian") regularly produced identity creating and consumer-oriented content, observers inclined toward irony wondered if Deleuze and Guattari could be seen as having inspired the latest wave of digital media and journalism. Around this time, and in part by following the example of new Buzzfeed model of media production, participatory interaction with journalistic and media content was largely reduced to "sharing" (John, 2013), "forwarding", "commenting on", and so on. This viral orientation, however, itself depended on quasiparticipatory media platforms like Facebook and Twitter for its' reach and ultimate financial success or failure. Buzzfeed thus both prefigured the orientation of the second and far more meaningful wave of participatory media practice, as well as found itself structurally dependent on these corporate, participatory platforms. In this sense, the career of Jonah Peretti can serve as in insightful window into the transition between the earlier, more utopian discourses characterized by the first two case studies, with the more dystopian discursive turn in the years that followed.

Despite the chuckles evinced by the knowledge that the founder of a highly successful digital website had once been something of a left-wing theory poseur, the relevant moments of Peretti's career to the epistemology of participation can actually be found elsewhere. These moments include his time at the MIT Media Lab (during which he created the "Nike viral sweatshop logo" meme that would launch his career), his later tenure at Eyebeam (the New York City-based digital arts organization), and finally, the often-fraught relationship between Buzzfeed's quality journalism and Facebook. Peretti's time at UC Santa Cruz can be seen as the "Counterculture to Cyberculture-esque" link between Peretti's career and the world of Silicon Valley; his later years might be seen as the creation of an East Coast, journalism, and oldmedia variation of that same story.

Peretti first rocketed to media attention in 2005 when he created the "Nike Sweatshop Email", which involved him trying to convince Nike's lawyers to personalize his pair of Shoes with the word "Sweatshop", a satire that drew attention to Nike factory working conditions and landed Peretti on Good Morning America and other media shows. At the time, as Peretti writes, he was at the MIT Media Lab:
Procrastinating writing my thesis[,] I visited the Nike ID website to check out the shoe personalization technology....The site was trumpeting the service as being about freedom and I thought this was ironic considering the way the shoes are actually made. That is how I got the idea to order a pair of running shoes customized with the word "sweatshop". (Chung, 2005)

By publicizing the rather deadpan and exchange of emails with Nike, Peretti's political stunt "went viral", a phrase which was not widely known in 2005. The experience led him towards a general interest in the qualities of digital media content that could lead to a rapid diffusion across a social network, and also to founding a second specific project, "The Contagious Media Project", house at the NYC based digital arts collective Eyebeam. The activities of the Contagious Media Group were eventually featured in a "Contagious Media" exhibition at New York City's New Museum, curated by Peretti and his sister, the comedian Chelsea, and included digital artworks like "Black People Love Us" (a parody of condescending white urbanites attitudes toward African-Americans), "The Rejection Line", (an answering machine number you could give to an unwanted solicitor at a bar or party), and the story of the original Nike email. By the moment the Contagious Media project debuted, however, Peretti had moved on to establish the Huffington Post with media entrepreneur and sometime political gadfly Arianna Huffington. From the Huffington Post Peretti would go on to establish Buzzfeed, where he would put his years of studying viral media to commercial use.

The commercial potential of the viral media experiments is obvious in retrospect; what is remarkable is how edgy and experimental they seemed at the timeexperimental enough to be featured in a major $\mathrm{New}$ York City museum. But not everyone was impressed. As Tom Moody, a NYC artist, musician, and sometime Eyebeam volunteer wrote in his memories of Peretti's time at Eyebeam:

I remember [Corey] Arcangel telling me about his contagious media group that met once a week, or month. I thought it sounded, to use a term from theory, "deeply full of shit". I understood that a business person or advertiser might want to study viral flow but why would an artist care about that? So you could goose your own stats? Make better animated GIFs? This was 2004. Peretti left Eyebeam to do terrible work at the Huffington Post and then terrible work at Buzzfeed. (Moody, 2014)

The final development in this transition from what we might call a "boutique" to a "mass market" understanding of participatory journalistic values can be seen in the manner by which the values of Buzzfeed, with its promiscuous mix of high-level investigative journalism, viral content, and participatory sharing, intersected with the institutions that were just beginning to colonize the me- 
dia landscape in the mid 2010s-platforms (Bogost \& Montfort, 2009; Gillespie, 2010; Helmond, 2015). These platforms-which include Twitter but are dominated by YouTube and Facebook-represent the full flowering of the participatory ethos insofar as their entire operational model depends on users voluntarily producing and sharing media content about themselves, their personal lives, and their beliefs. For news organizations that make use of these platforms, the key question is how to crack the algorithmic code in a way that contribute to the bottom line.

Perhaps some of these darker developments were foreshadowed in Peretti's earliest work. Black People Love Us, in particular, provoked a number of extreme and hostile reactions across the political spectrum, leading Peretti to conclude that "you can't pick your audience" when you depend on virality for distribution. While the website was designed to critique subtle racism and clueless comments made by white Americans with African-American friends:

The site eventually spread to message boards run by white power groups who were outraged by the pictures of whites and blacks socializing. I started to get threatening phone calls from angry KKK members in the middle of the night. "May I please speak to Johnny?" one of them asked in a polite southern accent, and then he broke into a racist, expletive filled death threat. (Chung, 2005)

Despite the common tendency to see participatory media as an unallowed good, even in the high days of participatory platforms, it was clear that darker and more illiberal forces were lurking on the horizon. We turn to a discussion of those forces in the final main section.

\section{Participatory Apocalypse: Pepe the Frog}

The realization that capitalism has fully captured the internet was to be expected and is in itself an insufficient explanation for the most recent deflation of the value of participation. Despite the fact that platform owners learned to thoroughly monetize user engagement and steer it in directions to make it even more profitable (van Dijck, 2013), a certain faith in the progressive political potential of participatory media remained. Liberals still easily squared the possibility of promoting a more inclusive and democratic society by means of the internet with doing this in the service of the Mark Zuckerbergs of this world and their shareholders. Awareness of dark corners of the internet notwithstanding, civic life was mostly not affected by them. In media scholarship, anti-democratic capabilities of social media were mostly explored in the context of semi-authoritarian regimes (Howard \& Parks, 2012).

McDonald's (2015) discussion of the conflicting orientations of digital culture captures an ambiguity of participation which has long ripened and would soon spread its more acerbic flavor: on the one hand, there is the "radical transparency" promoted by Facebook, on the other hand the collaborative initiatives exemplified by Anonymous-involving masking (iconographical as well as identificatory), embracing the ephemeral and the grotesque, and memeification. We are now in a much better (or worse) position to see different combinations of these two orientations: circulation of destructive ideas on "radically transparent" platforms, untraceable and detached from their unidentifiable originators; sowing conflict and destruction of reputation of people who are (personally or professionally) compelled to expose themselves on social media; etc. Peretti's experience with "Black People Love Us" has come to dominate participatory media space.

The rising problem consciousness of trolling and memeification in the context of various right-wing populist campaigns, particularly the 2016 US presidential election, has devalued participation in journalism. Rather than voicing citizens' concerns and fostering reasoned dialogue, the internet now appeared to drown out these voices and only amplify the most outrageous and obnoxious. The consequences of this, however, were not merely understood discursively. As Ryan Milner told The Guardian, what the Pizzagate conspiracy exemplified was "that playful buzzing participation...[may turn] into real consequences" (Wilson, 2017). The ironically distanced and boundary-crossing pose of the troll (Phillips, 2015) paved the way for loose alliances between citizens, campaign strategists, and political radicals generating attention and solidarities through memes with ambiguous messages. This created a sense in journalism that the participating public could no longer be trusted and that it perhaps should not even trust itself: "With every election cycle, the citizenry seems to amass more and more tools for bending the online political narrative to their will-or to feel as if they're doing so, anyway", reflected Amanda Hess (2016) about this loose alliance, which Republicans have become most effective at exploiting, four days before Trump was elected.

What gave the residual optimism about participation described earlier the deathblow was the rise of the altright from the depths of Reddit, 4chan, and 8chan, promoted by a newer sector of the media industry specializing in outrage (Berry \& Sobieraj, 2014), and consolidated around memes. Meme culture has taken a life of its own. It developed principles and forms of assigning value to its products as symbolic objects and thus followed how other fields of cultural production differentiate (Bourdieu, 1993). This is evidenced by the vigor of critical meta-discourse-whose existence is particularly pronounced in ascending media fields (Jacobs \& Townsley, 2017) - on such platforms as the internet magazine Meme Insider or the subreddit Meme Economy. This meme-appraising meta-discourse not only formed collective identity (Gal, Shifman, \& Kampf, 2015) but in assigning worth and establishing hierarchies structured the symbolic economy of meme production (Literat \& 
Van den Berg, 2017). With the foundation of its own stock exchange NASDANQ in 2017, meme culture is crossing the threshold to a "real" economy.

We argue that the later career of Pepe the Frog, a cartoon character who has risen to infamy as one of the most prevalent symbols of the alt-right and a weapon in the meme warfare of the 2016 US presidential election, is paradigmatic for this stage in the life cycle of participation. Characterized by his creator as a humanoid "chill frog-dude" with a stoner face who liked peeing with his pants down to his ankles (Furie, 2016), Pepe was conceived as anything but a symbol of hate. With the catchphrase "feels good man", Pepe's memeification began with emotive commentary, first in the original joyous sense, then in different alterations attached to various emotional states (Triple Zed, 2015). The meme circulated through the internet, from fringe sub-cultures to celebrities. When presidential candidate Trump retweeted a Pepe depicting himself in October of 2015, apparently strategically utilizing the connotation of this symbol, while the alt-right used Pepe not only to spread their propaganda but also to support their candidate, the association seemed undeniable and the meme got fully politicized.

By mid 2016, Pepe was considered a symbol of white nationalism in different news reports. The Daily Beast quoted a self-proclaimed "anonymous white nationalist" in a story published on May 26, 2015 who asserted there was a campaign to remove the symbol from mainstream culture and claim it for the alt-right by purposely connecting Pepe with Nazi propaganda (Nuzzi, 2016). Violent and clearly anti-Semitic Pepes, with swastikas and other more or less coded Nazi propaganda messages, gained attention and were discussed in various news reports.

It is an understatement to treat racist Pepes and other user-generated right-wing vitriol during the presidential campaign as propaganda. In the demonstrative breaching of established cultural norms (what conservatives often deride as political correctness) they are part of a concerted attack on democratic consensusunderstood as shared categories of purity and impurity through which people express and legitimize themselves in public (Alexander, 2006). The threat of continuous breaching of speech norms may constitute less a sustained switching of these cultural codes, which is what the liberal outrage against it conjures; besides outrage fatigue, the immediate threat is that by performatively embracing impure codes distracts from relatively mundane transgression of democratic principles (e.g., day-today racism).

Considering the growing body of media scholarship on this topic, we can see that the meaning attached to memes themselves have changed because of their role in consolidating the alt-right. Not too long ago, memes were discussed in terms of mostly politically innocent humor (Davison, 2012), viral marketing (Guadagno, Rem- pala, Murphy, \& Okdie, 2013), as means to generate political dialogue (Milner, 2013) or form collective identities (Gal et al., 2015). More recently, the focus has shifted towards more divisive and democratically corrosive manifestations of this cultural form (Ludemann, 2018; Topinka, 2017; Sparby, 2017). As a prime example of a symbol modified and reinterpreted by peerproduction, this has shed a much more pessimistic light on participation. As Topinka's study of the subreddit $\mathrm{r} / \mathrm{ImGoingToHellForThis} \mathrm{demonstrated,} \mathrm{"user-generated}$ content on participatory media can establish and promote racism and nationalism without requiring the sanction of an established publisher" (Topinka, 2017, p. 17). What seems to resonate with this more pessimistic outlook on participatory media is a peculiar sense of nostalgia for the Network era-a time of greater political consensus in American society-particular in arguments critical of the so-called filter bubbles (Pariser, 2011), which have been recently powerfully refuted (Bakshy, Messing, \& Adamic, 2015) or qualified (Faris et al., 2017).

Not only through active user engagement but simply by the fact how we can witness political discourse through them, participatory media have contributed to a heightened sense of polarization, affecting loyalties for and resentments against others, how citizens interact (and perhaps more importantly not interact) with each other, their decisions, including on who to vote for. Supported by evidence from political ethnographies (Cramer, 2016; Hochschild, 2016), Polletta and Callahan (2017) argued that white working-class resentment may be less about whether people have themselves experienced or witnessed discrimination than being part of stories which people like them share with each other about being discriminated. These stories get confirmed by media commentators who have made a business from telling their audience what other people think about them (Berry \& Sobieraj, 2014).

Efforts to reappropriate Pepe, above all by the \#SavePepe campaign launched by Pepe's creator Matt Furie himself, have so far been unsuccessful. ${ }^{2}$ But there are also more hopeful prospects: With the impact of the \#MeToo movement-effectively consolidated attention around the prevalence and persistence of sexual harassment and assault, encouraging mostly women to speak out about their experience, and holding sexual predators accountable-participation may be viewed again in a more nuanced, if not completely redeemed way.

\section{Conclusion}

The current meme-drenched political battles in the US and elsewhere shed light on three items we have approached through our case studies in this article: the relationship between participation, status, and identity, the dynamics affecting the relationship between mainstream and participatory journalism, and the political

\footnotetext{
${ }^{2}$ At the moment of writing this article, Furie has sued Infowars for copyright infringement for using Pepe in a poster which was sold on the site's online store (Sommerlad, 2018).
} 
role of counter-publics and subaltern movements and their relationship to participatory culture.

One of Jonah Peretti's deepest insights (one that influenced both the viral tendencies of 21st century journalism as well as journalism's relationship toward the platform power of Facebook and Twitter) was the link he drew between participation and identity. Perhaps most ironic about meme culture of the political right is that, even as it trades on breaching mainstream cultural norms and stylizing itself as culturally progressive and radical, it rigorously polices its own locutionary conventions, despite the ever-evolving rules of meme discourse (Milner, 2013; Miltner, 2014). Analogous to the pressure to refine cultural tastes in order to maintain class membership (Bourdieu, 1984), status in meme communities is elusive and members need to continuously refine and perform their cultural proficiency since illiteracy and breaking of conventions leads to scorns and exclusion (Nissenbaum \& Shifman, 2015).

To add further irony, this moment also realized one of the more hopeful visions of theorists of subaltern public spheres (Fraser, 1992; Habermas, 1996; Jacobs, 2000): communicative spaces in which shared interests can be formed and from which they can (ideally) be asserted in the dominant public sphere when pertinent normative questions are at stake. Dismissing the interests of Trump supporters as false consciousness does not detract from the uncomfortable reality that the internet gave many people the opportunity to find and express their previously unheard voices and make them heard, including by reproducing and modifying racist memes. Indymedia, as we have seen, was one of the earliest progenitors of these developments, promiscuously mixing participation, political identity, and agonistic politics, and deeply influencing journalism as a result.

Traditional journalism, finally, has been deeply divided by these developments. On a professional level, what should the relationship between journalists and citizen participants be? In economic terms, should journalists make use of amateur content in order to save money, and what are the institutional consequences if they do so? Politically, finally, how ought journalists reconcile the agonistic tendencies of citizen participation (discussed above) and their own traditional roles as neutral brokers between different ideological perspectives? Should journalists become more political themselves? Does using a piece of Indymedia content mean that journalists endorse and anarchistic, anti-global perspective? How about something featuring Pepe the Frog? Does it matter that one perspective is of the left, and one that is of the right? Why? What does this difference say about the potentially latent political tendencies of professional journalism?

Considering the history of participatory journalism across this longer time frame can, finally, help us get a better sense of how politics and media have changed across the arc of the early 21st century. Through the lens of the often unexpected and unanticipated devel- opments discussed in the previous section, we can get a sense of the different ways the cultural values and epistemologies of media making have refracted, split, and transformed. In order to meet the challenge of the present day-with its' problems both political and journalistic-we must know both where we have been and where we are going, and do so in relation to one of the dominant ideological impulses - that impulse to participate - of the digital age.

\section{Acknowledgments}

We would like to thank two anonymous reviewers, as well as Oscar Westlund and Matts Ekström, for their feedback on earlier versions of this article.

\section{Conflict of Interests}

The authors declare no conflict of interests.

\section{References}

Alexander, J. C. (2006). The civil sphere. New York, NY: Oxford University Press.

Anderson, C. W. (2013). Rebuilding the news: Metropolitan journalism in the digital age. Philadelphia, PA: Temple University Press.

Bakshy, E., Messing, S., \& Adamic, L. A. (2015). Exposure to ideologically diverse news and opinion on Facebook. Science, 348(6239), 1130-1132. https://doi.org/10.1126/science.aaa1160

Berry, J. M., \& Sobieraj, S. (2014). The outrage industry: Political opinion media and the new incivility. Oxford: Oxford University Press.

Boczkowski, P. J. (2004). Digitizing the news: Innovation in online newspapers. Cambridge, MA: MIT Press.

Bogost, l., \& Montfort, N. (2009). Racing the beam: The Atari video computer system. Cambridge, MA: The MIT Press.

Bourdieu, P. (1984). Distinction: A social critique of the judgement of taste. Cambridge, MA: Harvard University Press.

Bourdieu, P. (1993). The field of cultural production: Essays on art and literature. New York: Columbia University Press.

Chung, J. (2005). Jonah Peretti of Eyebeam. Gothamist. Retrieved from gothamist.com/2005/06/04/jonah_ peretti_director_of_rd_at_eyebeam.php

Cramer, K. J. (2016). The politics of resentment: Rural consciousness in Wisconsin and the rise of Scott Walker. Chicago, IL: University of Chicago Press.

Davison, P. (2012). The language of internet memes. In M. Mandiberg (Ed.), The social media reader (pp. 120-134). New York, NY: New York Univeristy Press.

Faris, R., Roberts, H., Etling, B., Bourassa, N., Zuckerman, E., \& Benkler, Y. (2017). Partisanship, propaganda, and disinformation: Online media and the 2016 US Presidential election. Cambridge, MA: The Berkman 
Klein Center, Harvard University.

Fraser, N. (1992). Rethinking the public sphere: A Contribution to the critique of actually existing democracy. In C. Calhoun (Ed.), Habermas and the public sphere (pp. 109-142). Cambridge, MA: MIT Press.

Furie, M. (2016, October 13). Pepe the frog's creator: He was never about hate. Time. Retrieved from time. com/4530128/pepe-the-frog-creator-hate-symbol

Gal, N., Shifman, L., \& Kampf, Z. (2015). "It gets better": Internet memes and the construction of collective identity. New Media \& Society, 18(8), 1698-1714. https://doi.org/10.1177/1461444814568784

Gans, H. J. (2004). Deciding what's news: A study of CBS Evening News, NBC Nightly News, Newsweek, and Time. Evanston, IL: Northwestern University Press. (Original work published 1979)

Garber, M. (2011, February 11). \#gave4andy: Andy Carvin and the ad hoc pledge drive. Niemanlab. Retrieved from www.niemanlab.org/2011/02/gave4 andy-andy-carvin-and-the-ad-hoc-pledge-drive

García de Torres, E., \& Hermida, A. (2017). The social reporter in action. Journalism Practice, 11(2-3), 177-194. https://doi.org/10.1080/17512786.2016. 1245110

Gillespie, T. (2010). The politics of platforms. New Media and Society, 12(3), 347-364.

Giraud, E. (2014). Has radical participatory online media really 'failed'? Indymedia and its legacies. Convergence, 20(4), 419-437. https://doi.org/10.1177/ 1354856514541352

Guadagno, R. E., Rempala, D. M., Murphy, S., \& Okdie, B. M. (2013). What makes a video go viral? An analysis of emotional contagion and Internet memes. Computers in Human Behavior, 29(6), 2312-2319. https://doi.org/10.1016/j.chb.2013.04.016

Habermas, J. (1996). Between facts and norms: Contributions to a discourse theory of law and democracy. Cambridge, MA: MIT Press.

Helmond, A. (2015). The platformization of the web: Making web data platform ready. Social Media + Society, 1(2), 2056305115603080.

Hermida, A. (2010). Twittering the news. Journalism Practice, 4(3), 297-308. https://doi.org/10.1080/ 17512781003640703

Hermida, A. (2012). Tweets and truth: Journalism as a discipline of collaborative verification. Journalism Practice, 6(5/6), 659-668. https://doi.org/10.1080/ 17512786.2012.667269

Hermida, A., Lewis, S. C., \& Zamith, R. (2014). Sourcing the Arab Spring: A case study of Andy Carvin's sources during the Tunisian and Egyptian revolutions. Journal of Computer-Mediated Communication, 19(3), 479-499. https://doi.org/10.1111/jcc4.12074

Hess, A. (2016, November 4). Memes, myself and I: The Internet lets us all run the campaign. The New York Times. Retrieved from www.nytimes.com/ 2016/11/06/arts/memes-myself-and-i-the-internetlets-us-all-run-the-campaign.htm
Hindman, M. S. (2009). The myth of digital democracy. Princeton, NJ: Princeton University Press.

Hochschild, A. R. (2016). Strangers in their own land: Anger and mourning on the American right. New York, NY: New Press.

Howard, P. N., \& Parks, M. R. (2012). Social media and political change: Capacity, constraint, and consequence. Journal of Communication, 62(2), 359-362. https://doi.org/10.1111/j.1460-2466.2012.01626.x

Jacobs, R. N. (2000). Race, media, and the crisis of civil society: From Watts to Rodney King. New York, NY: Cambridge University Press.

Jacobs, R. N., \& Townsley, E. (2017). Media metacommentary and the performance of expertise. European Journal of Social Theory, 21(3). https://doi.org/ 10.1177/1368431017740720

John, N. A. (2012). Sharing and Web 2.0: The emergence of a keyword. New Media \& Society, 15(2), 167-182. https://doi.org/10.1177/1461444812450684

Kreiss, D., \& Brennen, J. S. (2016). Normative Theories of digital journalism. In C. W. Anderson, D. Domingo, A. Hermida, \& T. Witschge (Eds.), Sage handbook of digital journalism studies. New York, NY: Sage.

Lasica, J. D. (2003, September 15). Benefits blogging brings to news outlets. Nieman Reports. Retrieved from niemanreports.org/articles/benefits-bloggingbrings-to-news-outlets

Lasorsa, D. L., Lewis, S. C., \& Holton, A. E. (2012). Normalizing Twitter: Journalism practice in an emerging communication space. Journalism Studies, 13(1), 1936. https://doi.org/10.1080/1461670x.2011.571825

Literat, I., \& van den Berg, S. (2017). Buy memes low, sell memes high: Vernacular criticism and collective negotiations of value on Reddit's MemeEconomy. Information, Communication \& Society. Advance online publication. https://doi.org/10.1080/1369118X. 2017.1366540

Livingston, S., \& Bennett, W. L. (2003). Gatekeeping, indexing, and live-event news: Is technology altering the construction of news? Political Communication, 20(4), 363-380. https://doi.org/10.1080/ 10584600390244121

Ludemann, D. (2018). /pol/emics: Ambiguity, scales, and digital discourse on 4chan. Discourse, Context \& Media, 24(August), 92-98. https://doi.org/10.1016/ j.dcm.2018.01.010

McDonald, K. (2015). From Indymedia to Anonymous: Rethinking action and identity in digital cultures. Information, Communication \& Society, 18(8), 968-982. https://doi.org/10.1080/1369118X.2015.1039561

Milner, R. M. (2013). Pop Polyvocality: Internet memes, public participation, and the Occupy Wall Street movement. International Journal of Communication, 7, 2357-2390.

Miltner, K. M. (2014). “There's no place for lulz on LOLCats": The role of genre, gender, and group identity in the interpretation and enjoyment of an Internet meme. First Monday, 19(8). http://dx.doi.org/ 
10.5210/fm.v19i8.5391

Molyneux, L., \& Mourão, R. R. (2017). Political journalists' normalization of Twitter. Journalism Studies. Advance online publication. https://doi.org/10.1080/ 1461670X.2017.1370978

Moody, T. (2014). Contagious media: A reminiscence. Tom Moody. Retrieved from www.tommoody.us/ archives/2014/05/22/contagious-media-a-reminis cence

Nissenbaum, A., \& Shifman, L. (2015). Internet memes as contested cultural capital: The case of 4chan's /b/ board. New Media \& Society, 19(4), 483-501. https://doi.org/10.1177/1461444815609313

Nuzzi, O. (2016, May 26). How Pepe the frog became a Nazi Trump supporter and alt-right symbol. The Daily Beast. Retrieved from www.thedailybeast.com/ articles/2016/05/26/how-pepe-the-frog-became-anazi-trump-supporter-and-alt-right-symbol

Pariser, E. (2011). The filter bubble: What the Internet is hiding from you. London: Penguin.

Parmelee, J. H. (2013). Political journalists and Twitter: Influences on norms and practices. Journal of Media Practice, 14(4), 291-305. https://doi.org/10.1386/ jmpr.14.4.291_1

Peters, J. D. (2009). Witnessing. In P. Frosh \& A. Pinchevski (Eds.), Media witnessing: Testimony in the age of mass communication (pp. 23-48). London: Palgrave Macmillan. https://doi.org/10.1057/ 9780230235762_2

Phillips, W. (2015). This is why we can't have nice things: Mapping the relationship between online trolling and mainstream culture. Cambridge, MA: The MIT Press.

Platon, S., \& Deuze, M. (2003). Indymedia journalism: A radical way of making, selecting and sharing news? Journalism, 4(3), 336-355. https://doi.org/ $10.1177 / 14648849030043005$

Polletta, F., \& Callahan, J. (2017). Deep stories, nostalgia narratives, and fake news: Storytelling in the Trump era. American Journal of Cultural Sociology. Advanced online publication. https://doi.org/10.1057/ s41290-017-0037-7

Quandt, T. (2018). Dark participation. Media and Communication, 6(4), 36-48.

Ratto, M., \& Boler, M. (Eds.). (2014). DIY citizenship: Critical making and social media. Cambridge, MA: MIT Press.

Robinson, S. (2006). The mission of the j-blog: Recapturing journalistic authority online. Journalism, 7(1), 65-83. https://doi.org/10.1177/1464884906059428

Robinson, S. (2010). Traditionalists vs. Convergers. Convergence: The International Journal of Research into New Media Technologies, 16(1), 125-143. https://doi.org/10.1177/1354856509347719

Sigal, L. V. (1973). Reporters and officials: The organization and politics of newsmaking. Lexington, MA: D. C. Heath.

Silverman, C. (2011, April 8). Is this the world's best Twitter account? Columbia Journalism Review.
Retrieved from www.cjr.org/behind_the_news/is_ this_the_worlds_best_twitter_account.php

Singer, J. (2005). The political j-blogger. Journalism, 6(2), 173-198. https://doi.org/10.1177/ 1464884905051009

Sommerlad, J. (2018, March 7). Pepe the Frog's creator is suing InfoWars. The Independent. Retrieved from www.independent.co.uk/life-style/gadgets-and-tech/ news/pepe-the-frog-infowars-copyright-lawsuit-altright-alex-jones-matt-furie-white-supremacists-neoa8244001.html

Sparby, E. M. (2017). Digital social media and aggression: Memetic rhetoric in 4chan's collective identity. Computers and Composition, 45, 85-97. https://doi.org/10.1016/j.compcom.2017.06.006

Students for a Democratic Society. (1962). Port Huron Statement of the students for a democratic society (Manifesto). Retrieved from web.archive.org/ web/20090705062937/http://coursesa.matrix.msu. edu/ hst306/documents/huron.html

Team, T. (2016, February 11). With Twitter earnings, user base weakness, but better ad engagement drives earnings beat. Forbes. Retrieved from www. forbes.com/sites/greatspeculations/2016/02/11/with -twitter-earnings-user-base-weakness-but-better-adengagement-drives-earnings-beat

Topinka, R. J. (2017). Politically incorrect participatory media: Racist nationalism on $\mathrm{r} / \mathrm{ImGoingTo}$ HellForThis. New Media \& Society, 20(5), 1-20. https://doi.org/10.1177/1461444817712516

Triple Zed. (2015). Pepe the Frog. Know Your Meme. Retrieved from knowyourmeme.com/memes/pepethe-frog

Tuchman, G. (1978). Making news: A study in the construction of reality. New York, NY: Free Press. Turner, F. (2006). From counter-culture to cyber-culture: Stewart Brand, the whole earth network, and the rise of digital utopianism. Chicago, IL: University of Chicago Press.

van Dijck, J. (2013). The culture of connectivity: A critical history of social media. Oxford: Oxford University Press.

Wilson, J. (2017, May 23). Hiding in plain sight: How the "alt-right" is weaponizing irony to spread fascism. The Guardian. Retrieved from www.theguardian. com/technology/2017/may/23/alt-right-online-humor -as-a-weapon-facism

Wolfson, T. (2012). From the Zapatistas to Indymedia: Dialectics and orthodoxy in contemporary social movements. Communication, Culture \& Critique, 5(2), 149-170. https://doi.org/10.1111/j.1753-9137. 2012.01131.x

Wolfson, T. (2015). Digital rebellion: The birth of the cyber left. Urbana, IL: University of Illinois Press.

Zelizer, B. (2007). On "having been there": "Eyewitnessing" as a journalistic key word. Critical Studies in Media Communication, 24(5), 408-428. https://doi.org/10.1080/07393180701694614 


\section{About the Authors}

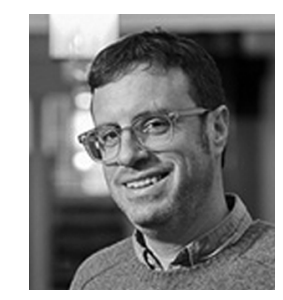

C.W. Anderson is Professor of Media and Communication at the University of Leeds and member of the board of advisors at the Tow Center, Columbia University Graduate School of Journalism. Professor Anderson studies journalism, politics, and how the production of public knowledge is being transformed in the digital age. He is the author, co-author, or co-editor of 4 books: Rebuilding the News (Temple University Press), The SAGE Handbook of Digital Journalism (with Tamara Witscghe, David Domingo, and Alfred Hermida); Remaking News (with Pablo Boczkowski, The MIT Press), and News: What Everyone Needs to Know (with Michael Schudson and Len Downie, Oxford University Press). He has written academic articles on digital journalism, sociology, political communication, and science and technology studies and more popular pieces for a variety of online websites and blogs. He is completing work on a manuscript tentatively titled Apostles of Certainty: Data Journalism and the Politics of Doubt (Oxford University Press). From 2000-2008 Chris was an editor and organizer at NYC Indymedia, one of the world's first "citizen journalism" websites. He received his PhD from Columbia University in 2009 under the supervision of Prof. James W. Carey and Prof. Todd Gitlin.

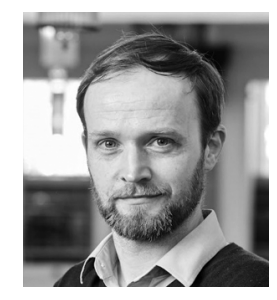

Matthias Revers is a Lecturer in Media and Communication at the University of Leeds. He is the author of Contemporary Journalism in the US and Germany (Palgrave US) and published articles on technological change and journalistic professionalism. His current research deals with political polarization, the moral boundaries of speech ("political correctness"), the establishment and enforcement of speech norms, and right-wing populist journalism. 